\title{
Pengaruh area pemasangan perangkat medik terhadap kejadian Medical Device Related Pressure Injuries (MDRPI)
}

\author{
Deliaty Bagenda ${ }^{1}$, Saldy Yusuf ${ }^{2}$, Rosyidah Arafat ${ }^{3}$, Muhammad Darwis ${ }^{4}$, Sintawati Majid ${ }^{5}$ \\ 1,2,3,5 Universitas Hasanudin, Indonesia \\ ${ }^{4}$ Rumah Sakit Dr. Wahidin Sudirohusodo, Indonesia \\ *Coresponding Author: deliatibagenda@gmail.com
}

\begin{abstract}
Abstrak
Pendahuluan: Cedera tekanan akibat penggunaan perangkat medis merupakan masalah akhir-akhir ini di mana jenis perangkat medis banyak digunakan di fasilitas kesehatan yang berguna sebagai intervensi dan diagnostik dan banyak terjadi pada perawatan intensif. Sebagian besar lokasi di daerah telinga karena penggunaan oksigen tetapi sampai sekarang upaya pencegahan MDRPI masih sangat kurang, sehingga berdampak pada kualitas layanan dan biaya. Tujuan: Untuk mengetahui kejadian MDRPI di ruang intensive care. Metode: Desain penelitian prospektif dan observasional menggunakan analisis deskriptif dan bivariat pada 39 pasien yang memiliki peralatan medis. Hasil: Responden sejumlah 39 lebih banyak jenis kelamin laki-laki dengan usia ratarata lebih dari 46 tahun. Sebanyak 8 responden mengalami MDRPI dengan jumlah hari pengobatan lebih dari 3 hari pada jenis perangkat intervensi $p>0,05$, uji Chi-Squere pada jenis perangkat memengaruhi area ekstremitas atas, bawah dan leher $(p<0,05)$. Simpulan: Penggunaan perangkat medis di fasilitas layanan berisiko mengalami cedera tekanan, secara signifikan mempengaruhi leher dan area ekstremitas. Oleh karena itu penilaian awal harus lebih
\end{abstract}

Kata kunci: Cedera tekanan; perangkat medis; MDRPI

The Effect of the area installation medical devices on the incidence of Medical Device Related Pressure Injuries (MDRPI)

\begin{abstract}
Introduction: Pressure injury due to the use of medical devices is a recent problem where the types of medical devices used in health facilities are useful as interventions and diagnostics and many occur in intensive care. Most of the locations in the ear area are due to the use of oxygen but until now MDRPI prevention efforts have still had very little impact on service quality and costs. Purpose: To see the incidence of MDRPI in the intensive care room. Methods: Prospective and observational study design using descriptive and bivariate analysis on 39 patients who have medical equipment. Results: Of the 39 respondents, there were more men with an average age of more than 46 years. A total of 8 respondents experienced MDRPI with the number of treatment days more than 3 days on the type of intervention device $p>.05$, the Chi-Squere test on the type of device affected the upper, lower limb and neck areas $(p<0.05)$. Conclusions: The use of medical devices in the service where pressure injury significantly affects the neck and limb area. Therefore the initial costs must be more
\end{abstract}

Keywords: Pressure injury; medical device; MDRPI

How to Cite: Bagenda, D., Yusuf, S., Arafat, R., Darwis, M., \& Majid, S. (2020). Pengaruh area pemasangan perangkat medik terhadap kejadian Medical Device Related Pressure Injuries (MDRPI). NURSCOPE: Jurnal Penelitian dan Pemikiran IImiah Keperawatan, 6(1), 1-8

\section{PENDAHULUAN}

Luka tekan akibat penggunaan alat (perangkat) medis atau Medical Device-Related Pressure Injuries (MDRPI) menjadi tantangan besar saat ini bagi para petugas kesehatan (Kim, Lee, \& Yu, 2017). Luka tekan umumnya terjadi pada daerah sakrum dan tumit, namun akhir-akhir ini juga banyak kejadian luka tekan akibat perangkat medis (MDRPI), data yang telah dilaporkan dari beberapa penelitian sebelumnya, seperti pada penelitian yang dilakukan di Amerika Serikat dan Kanada pada tahun 2016 ditemukan kasus MDRPI sebesar 
75\% (Kayser, Vangilder, Ayello, \& Lachenbruch, 2018), 41\% kasus juga telah ditemukan di Amerika Serikat (Arnold-Long et al., 2017), Australia (33\%) kasus (Monarca, Marteka, \& Breda, 2018), Belanda (31,8\%) kasus (Ham, Schoonhoven, Schuurmans, \& Leenen, 2017), Turki (34,5\%) kasus pada tahun 2013 (Hanonu \& Karadag, 2016), dan (40\%) kasus pada tahun 2014 (Karadag, Hanönü, \& Eyikara, 2017). Di Indonesia (24\%) kasus tahun 2017 pada anak (Widiati, Nurhaeni, \& Gayatri, 2017). Berdasarkan data-data tersebut menjelaskan bahwa begitu besarnya insiden MDRPI ini sehingga membutuhkan perhatian khusus termasuk dari petugas kesehatan ataupun perawatan tentang pengawasan pada area atau lokasi yang berisiko.

MDRPI berisiko terjadi pada area wajah. Pada penelitian yang dilaporkan MDRPI lebih banyak terjadi pada kepala atau leher seperti: leher bagian depan, dagu, daerah kepala bagian belakang, atau hidung (Apold \& Rydrych, 2012). Penelitian lain juga menyebutkan bahwa kasus MDRPI paling banyak terjadi pada area telinga (Arnold-Long et al., 2017), dan area hidung (Kayser et al., 2018), sedangkan yang paling sering pada daerah kepala, hidung, mulut, bibir, telinga, paha bagian belakang dan leher (Coyer, Stotts, \& Blackman, 2014). Risiko MDRPI dapat terjadi pada seluruh anggota tubuh akibat penggunaan perangkat medis sesuai dengan area pemasangan dan jenis alat yang digunakan.

Penggunaan perangkat medis dapat memberikan dampak sesuai dengan area dan jenis perangkat yang digunakan. Hasil penelitian tentang penggunaan NIV atau CPAP melaporkan bahwa perangkat medis merupakan salah satu faktor independen terhadap kerusakan kulit yang menyebabkan MDRPI (Yamaguti et al., 2014), penelitian serupa juga melaporkan hal yang sama mengenai dampak penggunaan NIV (Alqahtani \& Alahmari, 2018). Selain itu ada beberapa jenis perangkat medis lainnya yang dapat menyebabkan MDRPI seperti tabung oksigen, CPAP, BIPAP, splint (Arnold-Long et al., 2017). Penelitian lain juga menyebutkan bahwa kejadian MDRPI akibat penggunaan oksigen (Kayser et al., 2018). Penggunaan alat bantu pernafasan paling sering ditemukan sebagai penyebab kejadian MDRPI dari berbagai jenis perangkat medis, hal ini disebabkan karena frekuensi penggunaan oksigen lebih banyak digunakan pada ruang perawatan intensif sehingga risikonya juga lebih besar dibandingkan dengan perangkat medis lainnya.

Ruang intensif merupakan ruang perawatan yang lebih banyak menggunakan perangkat medis. Sebuah penelitian menyebutkan bahwa $68 \%$ kejadian MDRPI terjadi di ruang intensif dibandingkan dengan ruang perawatan biasa (Barakat-Johnson, Barnett, Wand, \& White, 2017), 1-3\% kejadian MDRPI terjadi di ruang intensif (J. M. Black \& Kalowes, 2016). Penelitian yang lain juga melaporkan bahwa sebanyak 0,8\% MDRPI terjadi pada ruang intensif (Chen, 2018). Kondisi pasien yang dirawat di ruang intensif membuat penggunaan perangkat medis lebih lama sehingga dapat berisiko mengalami MDRPI meskipun demikian hal tersebut dapat dicegah.

Luka tekan akibat penggunaan perangkat medis (MDRPI) menjadi perhatian akhir- akhir ini dimana penggunaan perangkat medis sangat banyak digunakan pada fasilitas kesehatan. Perangkat tersebut dapat berfungsi sebagai intervensi dan terapeutik (Black \& Kalowes, 2016). Kejadian MDRPI lebih banyak akibat penggunaan oksigen (Arnold-Long et al., 2017). Hal yang sama juga dilaporkan bahwa penggunaan oksigen menyebabkan MDRPI (Kayser et al., 2018). Penggunaan perangkat medis lebih banyak pada ruang intensif sehingga perawat memiliki tantangan besar dalam menghadapinya. namun sampai saat ini upaya dalam pencegahan MDRPI masih sangat kurang dilakukan sehingga memberikan dampak terhadap mutu pelayanan dan cost efectif. Adapun tujuan dari penelitian ini adalah untuk melihat hubungan antara jenis perangkat medic terhadap MDRPI

\section{METODE}

Desain penelitian yang digunakan adalah penelitian prospektif observasional. Sampel dalam penelitian ini adalah seluruh pasien yang dirawat di intensive care unit, high care unit, unit orthopedi, unit neurologi, unit urologi, unit onkologi, cardiovascular care unit, unit digestive. Kriteria inklusi yaitu pasien yang dirawat selama 24 jam pertama yang menggunakan perangkat medic kurang dari 2 minggu dan usia lebih dari 17 tahun. Pengambilan sampel menggunakan teknik probability sampling. Pasien yang mengalami luka tidak 
dimasukkan dalam sampel. Dari semua pasien yang dirawat di ruang intensif sebanyak 142 pasien hanya 39 pasien yang masuk kriteria inklusi dan menjadi responden.

Penelitian ini mengunakan lembar observasi dengan karakteristik demografi yang terdiri dari usia, jenis kelamin, pendidikan, riwayat kerja, status perkawinan dan suku, kemudian diagnosis medik dan hari rawat. Adapun pemeriksaan laboratorium terdiri dari darah rutin, analisa gas darah dan albumin. Area pemasangan perangkat yang menyebabkan luka tekan adalah area leher, wajah, ekstremitas atas dan ekstremitas bawah. Pengumpulan data dalam penelitian ini dengan melakukan observasi pada hari pertama, tiga, lima, tujuh, Sembilan, sebelas dan tiga belas dengan menggunakan lembar observasi berdasarkan jenis perangkat intervensi dan diagnostic. Peneliti melakukan informed consent dengan pasien dan keluarga tentang tujuan penelitian dengan mengisi persetujuan tertulis yang menyatakan bersedia menjadi responden serta menggunakan lemba observasi untuk melihat area penggunaan perangkat medik.

Penelitian ini dilakukan sesuai pedoman etik dan melalui persetujuan tertulis serta mendapatkan izin dari komite etik Univeritas Hasanuddin Nomor: 245 / UN4.6.4.5.31 / PP36 / 2019. Selama penelitian, pasien dan keluarga diberitahu tentang tujuan penelitian ini. Data dianalisa menggunakan SPSS versi 19 secara bivariat dan deskiriptif. Pada karakteristik demografi menggunakan uji pada Chi-Square, sedangkan hasil laboratorium dengan melihat standard deviasi dan mean. Untuk area pemasangan perangat medik menggunakan Mann Whitney.

\section{HASIL DAN PEMBAHASAN}

Karakteristik demografi responden

Pada penelitian ini populasi sebanyak 142 dengan sampel 39 yang memenuhi kriteria inklusi. Data demografi pada tabel 1 menjelaskan bahwa meskipun secara statistik tidak bemakna jenis kelamin laki laki lebih banyak dibandingkan perempuan (12,8\%) pendidikan sebagian besar adalah SMA $(15,4 \%)$, riwayat pekerjaan terbanyak pada wiraswasta $(15,4 \%)$, status perkawinan sebagian besar adalah sudah menikah dan berasal dari suku Makassar $(12,8 \%)$ serta usia rata rata $>46$ tahun. Status kesehatan sebagian besar dengan diagnosis lain $(7,7 \%)$ namun diagnose tumor dan trauma kepala $(5,1 \%)$ yang cendeung mengalami MDRPI. Adapun lama hari rawat yang mengalami MDRPI < 1 minggu $(17,9 \%)$ dan $>1$ minggu $(2,6 \%)$ ( Tabel 1 )

Tabel 1. Karakteristik demografi responden $(n=39)$

\begin{tabular}{|c|c|c|c|}
\hline & \multicolumn{2}{|c|}{ MDRPI } & \multirow{3}{*}{$\mathbf{p}$} \\
\hline & \multirow{2}{*}{$\begin{array}{c}\text { Tidak Terjadi } \\
\text { n: } \mathbf{3 1} \\
\end{array}$} & \multirow{2}{*}{$\begin{array}{c}\text { Terjadi } \\
\text { n: } 8 \\
\end{array}$} & \\
\hline & & & \\
\hline Usia (mean SD) & $(46,35 \pm 15,82)$ & $(36,00 \pm 19,06)$ & 0,12 \\
\hline \multicolumn{4}{|l|}{ Jenis Kelamin } \\
\hline Laki laki & $17(43,6 \%)$ & $5(12,8 \%)$ & \multirow[t]{2}{*}{0,697} \\
\hline Perempuan & $4(79,5 \%)$ & $3(20,5 \%)$ & \\
\hline \multicolumn{4}{|l|}{ Pendidikan } \\
\hline SD & $6(15,4 \%)$ & $0(0,0 \%)$ & \multirow{4}{*}{0,571} \\
\hline SMP & $3(7,7 \%)$ & $1(2,6 \%)$ & \\
\hline SMA & $20(51,3 \%)$ & $6(15,4 \%)$ & \\
\hline Sarjana & $2(5,1 \%)$ & $1(2,6 \%)$ & \\
\hline \multicolumn{4}{|l|}{ Suku } \\
\hline Makassar & $11(28,2 \%)$ & $5(12,8 \%)$ & \multirow{4}{*}{0,460} \\
\hline Bugis & $15(38,5 \%)$ & $3(7,7 \%)$ & \\
\hline Toraja & $4(10,3 \%)$ & $0(0,0 \%)$ & \\
\hline Lainnya & $1(2,6 \%)$ & $0(0,0 \%)$ & \\
\hline
\end{tabular}




\begin{tabular}{|c|c|c|c|}
\hline & \multicolumn{2}{|c|}{ MDRPI } & \multirow{3}{*}{$\mathbf{p}$} \\
\hline & Tidak Terjadi & Terjadi & \\
\hline & $\mathrm{n}: \mathbf{3 1}$ & $\mathrm{n}: 8$ & \\
\hline \multicolumn{4}{|l|}{ Status Perkawinan } \\
\hline Tidak Menikah & $6(15,4 \%)$ & $4(10,3 \%)$ & \multirow{2}{*}{0,770} \\
\hline Menikah & $25(64,1 \%)$ & $4(10,3 \%)$ & \\
\hline \multicolumn{4}{|l|}{ Pekerjaan } \\
\hline IRT & $5(12,8 \%)$ & $1(2,6 \%)$ & \multirow{7}{*}{0,102} \\
\hline Belum Bekerja & $4(10,3 \%)$ & $1(2,6 \%)$ & \\
\hline PNS & $3(7,7 \%)$ & $0(0,0 \%)$ & \\
\hline Petani & $6(15,4 \%)$ & $0(0,0 \%)$ & \\
\hline Wiraswasta & $6(15,4 \%)$ & $6(15,4 \%)$ & \\
\hline Swasta & $3(7,7 \%)$ & $0(0,0 \%)$ & \\
\hline Lainnya & $4(10,3 \%)$ & $0(0,0 \%)$ & \\
\hline \multicolumn{4}{|l|}{ Diagnosa Medik } \\
\hline Tumor & $10(25,6 \%)$ & $2(5,1 \%)$ & \multirow{5}{*}{0,039} \\
\hline Trauma spinal & $1(2,6 \%)$ & $1(2,6 \%)$ & \\
\hline Trauma Brain Injury & $0(0,0 \%)$ & $2(5,1 \%)$ & \\
\hline $\begin{array}{l}\text { Gangguan } \\
\text { Pencernaan }\end{array}$ & $3(7,7 \%)$ & $0(0,0 \%)$ & \\
\hline Lainnya & $17(43,6 \%)$ & $3(7,7 \%)$ & \\
\hline \multicolumn{4}{|l|}{ Hari rawat } \\
\hline$\leq 1$ minggu & $27(69,2 \%)$ & $7(17,9 \%)$ & \multirow{2}{*}{0,976} \\
\hline$>1$ minggu & $4(10,3 \%)$ & $1(2,6 \%)$ & \\
\hline
\end{tabular}

Pengaruh hasil laboratorium dengan kejadian MDRPI

Hasil laboratorium merupakan salah satu faktor risiko MDRPI seperti albumin, darah rutin dan analisa gas darah. Secara statistik diperoleh hasil laboratorium tidak signifikan dengan nilai $p>0,05$ ( Tabel 2 )

Tabel 2. Pengaruh Hasil Laboratorium Dengan MDRPI ( $n=39$ )

\begin{tabular}{lcrrrr}
\hline \multirow{2}{*}{ Pemeriksaan Darah } & \multicolumn{2}{c}{ Tidak Terjadi } & \multicolumn{2}{c}{ Terjadi } & $\boldsymbol{p}$ \\
\cline { 2 - 6 } & \multicolumn{1}{c}{$\mathbf{N}$} & mean, SD & $\mathbf{n}$ & \multicolumn{1}{c}{ mean, SD } & \\
\hline WBC $\left(\mathrm{mm}^{3}\right)$ & $\mathrm{n}: 31$ & $18,65 \pm 14,13$ & $\mathrm{n}: 8$ & $14,10 \pm 4,50$ & 0,387 \\
$\mathrm{RBC}\left(\mathrm{mm}^{3}\right)$ & $\mathrm{n}: 31$ & $15,37 \pm 64,55$ & $\mathrm{n}: 8$ & $4,22 \pm 1,00$ & 0,631 \\
$\mathrm{Hb}(\mathrm{g} / \mathrm{dl})$ & $\mathrm{n}: 31$ & $16,77 \pm 23,84$ & $\mathrm{n}: 8$ & $11,54 \pm 2,76$ & 0,543 \\
Hct $(\%)$ & $\mathrm{n}: 31$ & $39,10 \pm 19,72$ & $\mathrm{n}: 8$ & $35,08 \pm 8,03$ & 0,579 \\
Plt (mm $\left.{ }^{3}\right)$ & $\mathrm{n}: 31$ & $262,97 \pm 158,02$ & $\mathrm{n}: 8$ & $232,00 \pm 205,50$ & 0,645 \\
Alb (g/dl) & $\mathrm{n}: 31$ & $101,23 \pm 298,78$ & $\mathrm{n}: 8$ & $6,71 \pm 10,66$ & 0,381 \\
PH (mmol/L) & $\mathrm{n}: 31$ & $842,26 \pm 184,50$ & $\mathrm{n}: 8$ & $10,64 \pm 0,04$ & 0,211 \\
PCO2 (mmHg) & $\mathrm{n}: 31$ & $782,59 \pm 407,43$ & $\mathrm{n}: 8$ & $663,41 \pm 467,99$ & 0,478 \\
HCO3 (mEq/L) & $\mathrm{n}: 31$ & $380,36 \pm 84,16$ & $\mathrm{n}: 8$ & $46,54 \pm 61,73$ & 0,054 \\
\hline
\end{tabular}

Gambaran lokasi atau area dengan kejadian MDRPI

Dalam penelitian ini kejadian MDRPI dengan total perangkat medik sebanyak 19 perangkat secara statistik terjadi dileher, ekstremitas atas dan bawah $(p<0,05)$, sedangkan pada wajah tidak ada hubungan $(p>0,05)$. Area penggunaan perangkat medic lebih banyak digunakan di area wajah dari perangkat intervensi $(74,50 \%)$ 
dibandingkan perangkat diagnostic (26,50\%) sedangkan pada area ekstremitas atas perangat diagnostik lebih banyak digunakan $(75,48 \%$ ) ( Tabel 3 ).

Tabel 3. Gambaran lokasi atau area dengan MDRPI ( $n=39)$

\begin{tabular}{lccc}
\hline \multirow{2}{*}{ Regio } & \multicolumn{3}{c}{ Perangkat } \\
\cline { 2 - 4 } & Intervensi & Diagnostik & \\
& $\mathbf{n}(\%)$ & $\mathbf{n}(\%)$ & 0,395 \\
Wajah & $26(74,50)$ & $1(26,50)$ & 0,001 \\
Torso ( Leher ) & $13(48,53)$ & $13(52,47)$ & 0,001 \\
Extremitas Atas & $11(25,52)$ & $24(75,48)$ & 0,001 \\
Extremitas Bawah & $13(73,12)$ & $5(27,88)$ & \\
\hline
\end{tabular}

Hubungan ruang perawatan terhadap MDRPI berdasarkan tanda

Ruangan perawatan pada pelayanan kesehatan berisiko terhadap kejadian MDRPI, namun ruang perawatan intensive lebih besar dibandingkan dengan ruang perawatan biasa. Dari 7 ruang perawatan ditemukan sebanyak $11,1 \%$ mengalami kemerahan pada pasien yang menggunakan perangkat medic dan terjadi luka $(5,6 \%)$ di ruang intensive care dan sebanyak 5,6 \% masing-masing terjadi di ruang neurologi, ortopedi, dan Onkologi yang tandai dengan kemerahan ( Tabel 4 )

Tabel 5. Hubungan ruang perawatan terhadap MDRPI berdasarkan tanda ( $n=39$ )

\begin{tabular}{lllll}
\hline \multirow{2}{*}{ Ruangan } & \multicolumn{3}{c}{ Tanda MDRPI } & $\mathrm{p}$ \\
\cline { 2 - 5 } & Tidak ada (\%) & Merah (\%) & Luka (\%) & \\
\hline Neuro & $4(22,2)$ & $1(5,6)$ & $0(0)$ & \\
Orthopedi & $2(11,1)$ & $1(5,6)$ & $0(0)$ & \\
Urologi & $2(11,1)$ & $0(0)$ & $0(0)$ & 0,37 \\
Digestive & $2(11,1)$ & $1(5,6)$ & $0(0)$ & \\
ICU & $1(5,6)$ & $2(11,1)$ & $1(5,6)$ & \\
CVCU & $0(0)$ & $1(5,6)$ & $0(0)$ & $0(0)$ \\
Onkologi & $0(0)$ & $0(0)$ & 0 & \\
\hline
\end{tabular}

Cedera tekan (PI) yang terbentuk karena perangkat medis adalah fenomena klinis yang layak mendapat perhatian dari profesional perawatan kesehatan (Kayser et al., 2018). Luka akibat perangkat medis ( MDRPI ) didefinisikan sebagai cedera akibat penggunaan perangkat dengan tujuan intervensi dan diagnostic (J. Black et al., 2015), cedera yang mengikuti bentuk perangkat dan berdasarkan dengan stage (Edsberg et al., 2016). MDRPI merupakan cedera local pada area kulit atau jaringan dibawahnya akibat adanya tekanan dari pemasangan perangkat medis eksternal yang menggambarkan bentuk dari perangkat yang terpasang pada area yang luka sedangkan cedera tekanan membrane mukosa adalah cedera yang ditemukan pada membran mukosa (National Pressure Ulcer Advisory Panel,(NPUAP), 2016). Penggunaan perangkat medic dilayanan kesehatan yang sangat banyak digunakan menyebabkan risiko prevalensi meningkat. Prevalensi MDRPI di Amerika Serikat dan Australia sebesar 3-1\% (Coyer et al., 2014). Data Internasional pada tahun 2016 MDRPI sebesar 75\% (Kayser et al., 2018). Sejalan dengan itu penelitian di Amerika Serikat juga dilaporkan MDRPI sebesar 50\% (Arnold-Long et al., 2017). Pada tahun 2015 dilaporkan bahwa 50\% MDRPI (Monarca et al., 2018).

Data Demografi: Hasil penelitian ini menunjukkan bahwa perlu diperhatikan ada beberapa factor yang mempengaruhi terjadinya MDRPI diantaranya adalah usia dan jenis kelamin dimana pasien usia lanjut lebih banyak mengalami MDRPI. Sebuah penelitian melaporkan bahwa usia lanjut $(67,4 \pm 16,1$ tahun) mempunyai resiko lebih tinggi (Hanonu \& Karadag, 2016), hal ini juga sesuai dengan penelitian lainnya bahwa usia rata rata yang mengalami MDRPI adalah 60-5 tahun dan sebagian besar adalah laku laki (Coyer et al., 2014). Pada 
penelitian yang dilaporkan bahwa $26 \%$ usia lanjut (71-80 tahun) dengan jenis kelamin laki-laki (74\%) lebih banyak mengalaami MDRPI (Barakat-Johnson et al., 2017). Usia rata rata yang dilaporkan pada penelitian lain yaitu 57,2 $\pm 9,0$ tahun serta 76,0\% terjadi pada laki laki (Mehta, Ali, Mehta, George, \& Kumar, 2018). Dengan demikian pasien usia lanjut jenis kelamin laki laki.yang menggunakan perangkat medic perlu observasi lebih sering oleh karena sangat berisiko mengalami MDRPI,

Status kesehatan : MDRPI juga dapat dipengaruhi oleh diagnosa medic pasien dan lama hari rawat selama menggunakan perangkat medik. Penelitian lain yang melaporkan bahwa penyakit system cardiovaskuler dan neurologis merupakan diagnose terbanyak $(28,0 \%)$ dengan penggunaan perangkat diagnostic cervical collar selama $>2$ hari mengalami kerusakan kulit sebanyak 23,7\% (Hanonu \& Karadag, 2016). Dalam evaluasi klinik penelitian yang lain bahwa pasien yang memakai cervical collar $<5$ hari, terdapat $33 \%$ mengalami MDRPI kemudian pasien yang menggunakan $>5$ hari, $44 \%$ mengalami MDRPI (Davis, W.James.MD, Parks, Detlefs, \& L.Corey, 1995). Pada kasus trauma brain injury yang menggunakan neck collar dan dirawat di rumah sakit $>2$ hari merupakan penyebab paling banyak terhadap MDRPI (Apold \& Rydrych, 2012). Penggunaan oksigen oronasal lebih dari > 26 jam merupakan factor independent terjadinya MDRPI (Yamaguti et al., 2014). Penelitian yang menjelaskan bahwa rata rata pasien yang dirawat di icu dengan lama hari rawat $>1$ minggu dan menggunakan perangkat medic oksigen dan NGT mengalami MDRPI (Mehta et al., 2018). Oleh karena itu penggunaan perangat medic sesuai dengan kondisi pasien berdasarkan diagnose medic sangat berisiko mengalami MDRPI begitupula dengan lama hari rawat dalam menggunakan perangkat medic tersebut.

Hasil laboratorium : Faktor risiko yang menyebabkan cedera pada kulit pada pasien yang dirawat di ruang intensif dapat diakibatkan oleh hipoalbuminemia, oksigenasi yang kurang, mobilitas yang menurun, gangguan fungsi kognitif, demam, kondisi kulit yang buruk karena penuaan atau penggunaan steroid (Conley, McKinsey, Ross, Ramsey, \& Feeback, 2014). Penelitian lain menjelaskan bahwa nilai haemoglobin dan albumin yang rendah merupakan factor resiko terjadinya MDRPI (Hanonu \& Karadag, 2016). Sebuah penelitian yang menjelaskan bahwa nilai haemoglobin kurang dari 9,0 dapat berkontribusi terjadinya MDRPI (Mehta et al., 2018), Albumin yang kurang merupakan factor yang mempengaruhi terjadinya luka pada daerah kepala (Kim et al., 2017), namun temuan ini tidak mempunyai hubungan antara hasil laboratorium dengan MDRPI, walaupun demikian hasil laboratorium harus di perhatikan sebagai penunjang dari MDRPI.

Area : MDRPI bervariasi berdasarkan area perangkat yang digunakan. Pada penelitian ini area yang banyak ditemukan pada leher, ekstremitas atas dan bawah dibandingkan wajah. Adapun berbagai jenis alat yang dapat menyebabkaan MDRPI yaitu Naso Gastric Tube, Endotracheal tube, Nasal Canule, Oxigen tubing, Cervical Collars, Oximetry Probes, NIV/BIPAP, Tracheostomy tubes, Tracheostomy braces, Drain, Central Vena Pressure, Cateter, Stoma bag, Arteri line, IV line, Elastis Verband, Neck collar, Splint, Pad elektroda, Restrain, NIBP (J. Black et al., 2015). Temuan pada sebuah penelitian bahwa MDRPI lebih banyak terjadi pada area leher akibat penggunaan neck kollar (Apold \& Rydrych, 2012), begitu juga pada penelitian lain yang menemukan lebih banyak pada leher akibat pengunaan tracheostomi (Jaul, 2011).

Penelitian lain juga menjelaskan bahwa penggunaan perangkat yang mengakibatkan MDRPI yaitu area dada akibat penggunaan tabung pengelola feses $(14,7 \%)$, Cateter $(14,7)$, area wajah akibat pengunaan nasal kanul (12,9\%-47\%), ETT (10,5\%), NGT (8\%), dan area leher akibat trcheostomi (8,1\%), (J. M. Black \& Kalowes, 2016). Namun berbeda dengan penelitian lainnya bahwa MDRPI lebih sering pada area ekstremitas $(21,6 \%)$ akibat penggunaan perangkat strain (Ham et al., 2017), Penelitian lain juga mengatakan area telinga terbanyak akibat perangkat pernafasan (Arnold-Long et al., 2017). Penelitian yang sama ditemukan MDRPI sebanyak $87,5 \%$ terjadi pada telinga akibat penggunaan oksigen (Barakat-Johnson et al., 2017) dan pada hidung akibat penggunaan oksigen (Kayser et al., 2018). MDRPI juga terjadi pada wajah akibat penggunaan oksigen dan NGT (Mehta et al., 2018). Oleh karena itu semua perangkat medik yang digunakan dapat menyebabkan terjadinya MDRPI, hal ini disebabkan karena adanya tekanan dari perangkat tersebut sehingga pengkajian awal yang comprehensive merupakan salah satu strategi pencegahan yang dapat dilakukan di seluruh ruang perawatan pada pasien yang menggunakan perangkat medik. 
Ruangan : Dari hasil penelitian cross sectional melaporkan bahwa MDRPI ditemukan sebanyak 9.1\% pada ruang intensive care (Vangilder, Amlung, Harrison, \& Meyer, 2009) dan pada penelitian yang lain juga menjelaskan bahwa lebih banyak (68,0\%) ditemukan MDRPI pada ruang intensive care dibandingkan dengan ruangan lain (Barakat-Johnson et al., 2017). Hal ini dapat disebabkan karena banyaknya penggunaan perangat medic yang digunakan pada ruang intensive dibandingkan ruang lainnya sehingga kejadiannya lebih banyak. Salah satu faktor penyebab MDRPI karena adanya gesekan yang menyebabkan kerentanan di kulit (Brienza et al., 2015) dan penggunaan perangkat yang tidak sesuai dengan ukuran dapat menyebabkan luka dengan tanda eritema dan pucat hingga meluas ke dermis (Karadag et al., 2017). Dengan demikian adanya gejala awal yang ditimbulkan akibat penggunaan perangkat medic seperti adanya kemerahan / eritema, dapat dicegah sehingga tidak menimbulkan sehingga tidak menyebabkan kerusakan jaringan / otot.

Keterbatasan penelitian ini adalah sampel yang kurang. Data dianlisis hanya satu rumah sakit, Penelitian ini hanya berfokus pada resiko kejadian MDRPI saja tanpa melihat faktor resiko lain yang dapat berkontribusi terjadinya MDRPI seperti status gizi, penggunaan obat obatan, dan riwayat penyakit sebelumnnya. Waktu dalam observasi maksimal hingga hari ke 13 dan pasien yang pindah rawat ke perawatan selanjutnya tidak dilakukan observasi lagi.

MDRPI pada pelayanan kesehatan merupakan hal yang perlu mendapat perhatian dari petugas kesehatan. Perawat yang melakukan observasi selam 24 jam menjadi tantangan. Peran perawat dalam melakukan observasi, pencatatan dan pelaporan sangat penting karena dapat menjadi tolak ukur dalam menurunkan MDRPI. Salah satu cara yang dapat dilakukan adalah melakukan observasi pada kulit di area penggunaan perangkat medic khususnya pasien dengan hari rawat $<1$ minggu. Oleh karena itu direkomendasikan untuk penelitian selanjutnya pemeriksaan kulit yang rutin terhadap pasien yang menggunakan perangkat medic terhadap MDRPI.

\section{SIMPULAN DAN SARAN}

MDRPI merupakan cedera tekan akibat perangkat medis yang akhir ini menjadi perhatian khususnya dipelayanan kesehatan. Banyaknya jenis perangkat yang digunakan sehingga resiko MDRPI juga meningkat. Penggunaan perangkat medic pada area leher, ekstremitas atas dan bawah lebih banyak ditemukan dibandingkan pada wajah serta lebih sering terjadi pada ruang perawatan intensive dibandingkan ruang perawatan biasa. Strategi pencegahan dapat dilakukan dalam menurunkan MDRPI seperti pemeriksaan kulit pada sekitar perangkat yang terpasang.

\section{DAFTAR PUSTAKA}

Apold, J., \& Rydrych, D. (2012). Preventing Device-Related Pressure Ulcers, 27(1), 28-34. https://doi.org/10.1097/NCQ.0b013e31822b1fd9

Black, J. M., Cuddigan, J. E., Walko, M. A., Didier, L. A., Lander, M. J., \& Kelpe, M. R. (2010). Medical device related pressure ulcers in hospitalized patients, 7(5).

Black, J. M., \& Kalowes, P. (2016). Medical device-related pressure ulcers. Chronic Wound Care Management and Research, 3, 91-99. Retrieved from www.dovepress.com

Coyer, F. M., Stotts, N. A., \& Blackman, V. S. (2013). A prospective window into medical device-related pressure ulcers in intensive care. https://doi.org/10.1111/iwj.12026

Edsberg, L. E., Black, J. M., Goldberg, M., McNichol, L., Moore, L., \& Sieggreen, M. (2016). Revised National Pressure Ulcer Advisory Panel Pressure Injury Staging System. Journal of Wound, Ostomy and Continence Nursing, 43(6), 585-597. https://doi.org/10.1097/WON.0000000000000281 
Ham, W. H. W., Schoonhoven, L., Schuurmans, M. J., \& Leenen, L. P. H. (2017). Pressure ulcers in trauma patients with suspected spine injury: a prospective cohort study with emphasis on device-related pressure ulcers. International Wound Journal, 14(1), 104-111. https://doi.org/10.1111/iwj.12568

Hanonu, S., \& Karadag, A. (2018). A Prospective, Descriptive Study to Determine the Rate and Characteristics of and Risk Factors for the Development of Medical Device-related Pressure Ulcers in Intensive Care Units, 1-13.

Karadag, A., Hanönü, S. C., \& Eyikara, E. (2017). A Prospective, Descriptive Study to Assess Nursing Staff Perceptions of and Interventions to Prevent Medical Device-related Pressure Injury. Ostomy/wound Management, 63(10), 34-41. https://doi.org/10.25270/owm.2017.10.3441

Kayser, S. A., Vangilder, C. A., Ayello, E. A., \& Lachenbruch, C. (2018). Prevalence and Analysis of Medical Device-Related Pressure Injuries: Results from the International Pressure Ulcer Prevalence Survey, 31(6), 276-285.

Kim, J. S., Lee, S. J., \& Yu, J. H. (2017). Factors Predicting the Interface Pressure Related to Pressure Injury in Intensive Care Unit Patients, 47(6), 794-805.

Mehta, C., Ali, M., Mehta, Y., George, J. V, \& Kumar, M. (2018). MDRPU -an uncommonly recognized common problem in ICU : A point prevalence study. Journal of Tissue Viability, (December), 0-1. https://doi.org/10.1016/j.jtv.2018.12.002

Monarca, M. C., Marteka, P., \& Breda, K. (2018). Decreasing Incidence of Medical Device-Related Pressure Injuries in a Small Community Hospital: A Quality Improvement Project. Journal of Wound, Ostomy and Continence Nursing, 45(2), 137-140. https://doi.org/10.1097/WON.0000000000000419

Widiati, E., Nurhaeni, N., \& Gayatri, D. (2017). Medical-Device Related Pressure Injuries to Children in the Intensive Care Unit. Comprehensive Child and Adolescent Nursing, 40(1), 69-77. https://doi.org/10.1080/24694193.2017.1386973

Yamaguti, W. P., Moderno, E. V, Yamashita, S. Y., Gomes, T. G. M. C., Maida, A. L. V, Kondo, C. S., ... Brito, C. M. M. De. (2014). Treatment-Related Risk Factors for Development of Skin Breakdown in Subjects With Acute Respiratory Failure Undergoing Noninvasive Ventilation or CPAP, 15301536. https://doi.org/10.4187/respcare.02942 